\title{
Philippine Education System: Are we Moving Forward?
}

\author{
Fermin G. Castillo, Jr., Djonde F. Antiado, James Ryan P. Reblando
}

\begin{abstract}
Different countries around the world has different rich history and heritage that surrounds their educational system. As old as history, we can trace the evolution of the Philippine education thru different era of colonialism which transform on what it is today. ASEAN integration, internationalization, $\mathrm{K}$ to 12 , Philippine qualifications framework, $21^{\text {st }}$ century skills to name a few are the main reasons for its development and change. The foundation of the education system is now competitive more than before and this is true in the case of higher education as the state provide them the necessary financial support and assistance. It is very important that this educational transformation will lead us to nation building and transform our society for a better and sustainable future. The role of government, private sectors, religious groups, $N G O$ 's and other parties involved are needed in order that future will looks promising otherwise it will move backward.
\end{abstract}

Keywords: Philippine education, competitiveness, knowledge, lifelong learning, sustainable future.

\section{INTRODUCTION}

Different countries around the world has different rich history and heritage that surrounds their educational system. As old as history, we can trace the evolution of the Philippine education thru different era of colonialism which transform on what it is today. ASEAN integration, internationalization, $\mathrm{K}$ to 12 , Philippine qualifications framework, $21^{\text {st }}$ century skills to name a few are the main reasons for its development and change. In fact, Philippine Education system is one of the most powerful today because they are able to inherit the best system in the past which includes Spanish education system, Japanese and American education system. As a result, they are able to combine the best practice which makes it to be one of the best. Thru the years because of limited budget the primary and secondary education suffered a lot because of lack of infrastructures, access to modern equipment, shortage of qualified teachers and more. Despite the challenges that the education system is facing they are able to convert that into a more promising approach in dealing with students by teaching core values and ethics which is very important relevant in today's modern world.

Revised Manuscript Received on October 31, 2019.

* Correspondence Author

Fermin G. Castillo, Jr.*, University of Sharjah, Sharjah, United Arab Emirates. Email: fcastillo@sharjah.ac.ae

Djonde F. Antiado, American College of Dubai, Dubai, United Arab Emirates. Email: arizdjonde@yahoo.com

James Ryan P. Reblando, MENA College of Management, Dubai, United Arab Emirates. Email: jamz9976@gmail.com
The Philippine education system benefitted from colonialism from Spain, Japan and United States. In fact, US colonialism had a long and formative impact on the development and progress of the Philippine education system. Most of the practice in the tertiary level are pattern in the American system such as credit hours, units, number of weeks and most importantly the medium of instruction which is English. During the golden years, the Philippine education is among the top in Asia and the world. Thru the years these glory days started to deteriorate because of many political and social problems that affects its progress. One of them is budget deficit and priority agenda of the Philippine government. With the advent of internationalization of education around the world, Philippines remains to be one of the few Asian countries with few affiliations and partners. The foundation of education system in the Philippines are stronger than before when they introduce the $\mathrm{K}$ to 12 Basic Education program. This landmark of excellence substantially boosts the years of instruction but preparedness of our learner to become locally and globally competitive.

\section{THE PHILIPPINE EDUCATION SYSTEM: OLD AND NEW SYSTEM}

In the span of ten (10) years, we have seen many reforms and transformation that happened in the Philippine Education system. But of course it is very important for us to understand the timeline of the whole education system as to it is today. Figure 1 below shows the timeline and history of different colonialism that transform the Philippine education system.

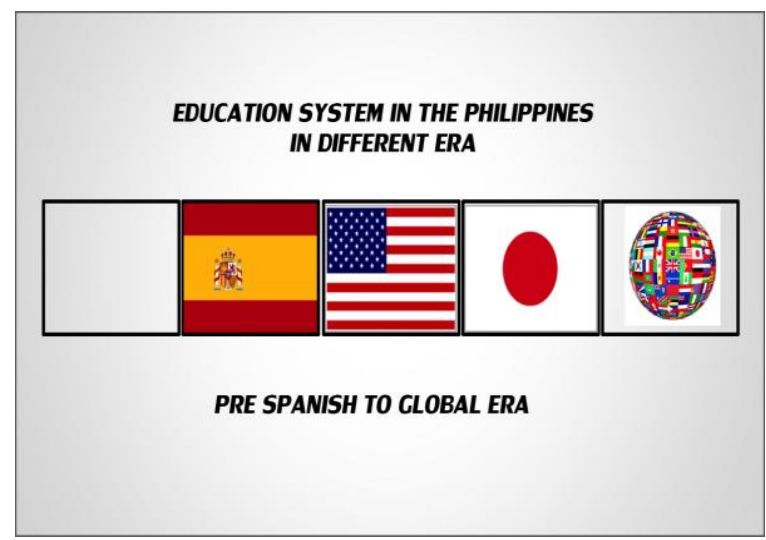

Fig. No. 1 Education System in the Philippines in Different Era [1] 
Before the Spanish occupancy the Philippine education system has no direction at all. This maybe because of the fact that Philippines is an archipelago with different dialect and languages to speak with. Meanwhile the during the Spanish era which is highly influential in nature because of its 300 years of long term dominant. The American introduces many reforms including the use of English language which until is being use as medium of instruction.

For few years the Japanese conquer the Philippines and they introduce new concepts of education like longer academic term/semester, love of country and flag and more. Fast forward in different era, we have seen that the educational system became stagnant thru the years including the budget deficit and shortage of qualified teachers in the primary and secondary level.

In terms of years of instruction, this is perhaps the most significant landmark in the Philippine Education System which was untouched for more than 65 years. In 2013, the basic education has been modified accordingly from 10 to 12 years. This evolution has mixed reception among parents and pupils but in the end the political will of the government to push thru on this prevail. This is a long term solution for a short term problem in the education system which require competitive infrastructure, manpower resources and more. This is not an easy implementation on the part of Department of Education (Philippines) but they are trying to take their stand. It's like now of never otherwise we will all regret that we did try.

Table No. I Education System according to years of instruction (all level)

\begin{tabular}{|l|l|c|c|c|}
\hline $\begin{array}{l}\text { Educatio } \\
\mathbf{n}\end{array}$ & School/Level & $\begin{array}{l}\text { Grad } \\
\text { es }\end{array}$ & Age & Years \\
\hline Primary & $\begin{array}{l}\text { Paaralang } \\
\text { Elementarya } \\
\text { (Elementary) }\end{array}$ & $1-6$ & $6-12$ & 6 \\
\hline $\begin{array}{l}\text { Secondar } \\
\text { y }\end{array}$ & $\begin{array}{l}\text { Paaralang } \\
\text { Pang } \\
\text { Sekundarya } \\
\text { (Secondary) }\end{array}$ & $7-10$ & $12-17$ & 4 \\
\hline $\begin{array}{l}\text { Vocation } \\
\text { al/ } \\
\text { Technical }\end{array}$ & & $11-14$ & $\begin{array}{c}16 / 17 \\
\text { abov } \\
\text { e }\end{array}$ & $\begin{array}{c}4 / 5 \\
\text { years }\end{array}$ \\
\hline $\begin{array}{l}\text { Tertiary } \\
\text { College/Unive } \\
\text { rsity }\end{array}$ & $15-16$ & - & $\begin{array}{c}\text { Week } \\
\text { s/ } \\
\text { years }\end{array}$ \\
\hline $\begin{array}{l}\text { Graduate } \\
\text { level }\end{array}$ & Masters & $17-19$ & - & $\begin{array}{c}2 / 3 \\
\text { years }\end{array}$ \\
\hline $\begin{array}{l}\text { Graduate } \\
\text { level }\end{array}$ & Doctorate & & & \\
\hline
\end{tabular}

Before a pupil can be admitted into grade 1 they are required normally to attend kindergarten to preschool. This is in preparation for toddlers for the next level. In fact, the biggest take away happened in this category with the passing of the "The Kindergarten Education Act of 2012 [2] that further strengthen the basic foundation of the learners. After the introduction of one year of mandatory Kindergarten education in 2011, the net enrollment rate in Kindergarten jumped from 55 percent (2010) to 74.6 percent in 2015 [3]. That is a huge milestone in terms of short span considering that the population of the Philippines started to increase every year. A budget of P2.39 billion was allotted to support Republic Act 10157, or the Kindergarten Education Act. The amount, which is covered by this year's P238.8-billion budget for basic education, will come from the 2012 General Appropriations Act [4]. With this new law, the Kindergarten Education Act will give more Filipino children a better and brighter foundation of their scholastic achievement. Starting school year 2013 this new law will take effect which makes this RA 10157 Kindergarten Program mandatory and compulsory for entrance to Grade 1.

Based from Table no. 1 we can say that 6 years of instruction as far as level is concern is normal in most countries around the world. In fact, the 6 years can be considered as standard basic education. In this case the Philippines is within at par with global standards. Thru the years we have seen that many countries focus on their tertiary level rather than the basic education as they enough budget compared to Philippines which is limited in nature. In the last 5 years the introduction of STEM in the basic education was in full force in many countries therefore we have to embrace such changes. Since we are new in the 12 years of instruction, can we still compete in a global scale? This can be answered by yes or no but somehow we have seen and compare what we have against other countries who already adopted to this priority of specialization.

Table No. II Education System according to years of instruction (Current)

\begin{tabular}{|l|l|l|l|c|}
\hline Education & $\begin{array}{l}\text { School/Leve } \\
\text { I }\end{array}$ & Grades & Age & Years \\
\hline Primary & $\begin{array}{l}\text { Paaralang } \\
\text { Elementarya } \\
\text { (Elementary) }\end{array}$ & $1-6$ & $6-12$ & 6 \\
\hline Secondary & $\begin{array}{l}\text { Paaralang } \\
\text { Pang } \\
\text { Sekundarya } \\
\text { (Secondary) } \\
\text { Junior High } \\
\text { School }\end{array}$ & $7-10$ & $12-17$ & 4 \\
\hline Secondary & $\begin{array}{l}\text { Senior High } \\
\text { School }\end{array}$ & $11-12$ & $17-18$ & 2 \\
\hline
\end{tabular}

\section{Note: Primary to Secondary level}

With the introduction of the K12 Program, the Philippine Education had been considered to be one of the few countries who adopted just lately the 12 nyears of basic education. In fact, The Philippines is now the only country in Asia that has a 10-year basic education cycle and one of the three remaining countries in the world, together with Djibouti and Angola of Africa, that retains a 10-year pre-university education system. [5] Being the last only means something but what matters the most is they adopt the global standards in the end. 
The added two-year Senior High Track aims to equip them with knowledge and skills that will help them prepare better for their chosen path -- be it higher education, employment, or entrepreneurship. [6] Under the added 2 years' program, the senior high school must choose a track as part of its preparation for the next level. They are classified into 4 namely: Academic Track, Technical-Vocational-Livelihood (TVL) Track, Sports Track, and Arts and Design Track. The changes on the years of instruction affected primarily the secondary level (high school) while the tertiary level stands the same and depends on the course to be taken.

The Enhanced Basic Education Act of 2013 [7] is the starting point of the process wherein many educators called it as the "game changer" in the Philippine Education system. We can say that it is really a game changer because it changes the 68 years of no movement in the basic education as far as years of instruction. Now that it is enforce since 2013, the bigger issue now here is this change will really improve our learners or it will just another burden to carry on. In fact, this changes will affect the tertiary level as admission to the collegiate level will be decline over the years. There is always a trade-off in any implementation that will determine the sustainable future of the learner. Senior High School (SHS) is the last two years of the $\mathrm{K}$ to 12 program that includes Grades 11 and 12. The tracks to be taken are explained below.

\section{Academic Track \\ This track appeals to those who have set their minds towards college education. Divided into degree-specific courses, the Academic track in senior high school aims to prepare students to more advanced university courses. Under this umbrella are four strands: \\ - $\quad$ General Academic (GA) \\ - Humanities and Social Sciences (HUMMS) \\ - $\quad$ Science, Technology, Engineering and Mathematics (STEM) \\ - Accountancy, Business and Management (ABM?}

\section{Technical-Vocational-Livelihood (TVL) Track}

It calls out to eligible students with subjects focused on job-ready skills. Besides, it offers practical knowledge with matching certificates to help students land their desired job after they graduate from SHS. Under the senior high school tech-voc track are the following strands.

\section{- $\quad$ Agri-Fishery Arts \\ - Home Economics \\ Industrial Arts}

- Information and Communications Technology
(ICT)
Sports Track
Developed to equip SHS students with sports-related
and physical fitness and safety knowledge, this track
appeals to those who wish to venture into athletics,
fitness, and recreational industries.
Arts and Design Track
Inside this course, students with a penchant for the Arts
can enroll in subjects that will hone their skills in visual
design and the performing arts.

Table No. III Description of Senior High School Tracks [8]

The academic tracks focus on the possible course(s) that the senior high school may take the moment they are in the collegiate level.

While they are in their last stage of senior years, this will be a preparation period for them so that they can adjust quickly to the course and profession they want to push thru. This is also true in the case of Tech-Voc as this tracks primarily targeting the skills of the learner. While other countries focused on the degree other focused on the competency and skills. At this point our senior high school has the edge over other applicants for the position. There are many countries in the region who look after the skills rather than the degree. In the case Canada which is one of the most ideal place for migration and work. They prioritize the skills of the foreign workers because this will contribute to the local and international employment. In the Middle East, which is the home of more than 7 million Filipinos abroad are exposed in working in hospitality management and health care. They have a high demanding job which the skills are their advantage over the degree. Aside from that Filipino workers have the ability to learn faster and adopt to the culture of the host countries. In terms of sports tracks, we can say that only few has the interest to be on this tracks. This is maybe because many of younger generations prefer to use different gadgets rather than focusing on this tracks. With the advent of ICT this can be a very powerful tools to be used by the learner in order to be more competitive. In fact, younger generations are more exposed to gadgets which will add value to their knowledge. In order to sustain their knowledge, expose them to modern technologies which will empower their knowledge to think of sustainable solutions for the future. Innovative ideas are around the corner, we just have to pick which one will really benefit the society and communities at large. Information and communications technology (ICT) as combined with modern education is perhaps the most important synergy that accelerated the globalization and mobility of people in the education sector. [9]

\section{COMPARING OLD AND NEW SYSTEM OF BASIC EDUCATION SYSTEM: K TO 12}

Comparing the Old System Vs. K-12 Education system will highlight its opportunities in preparation for lifelong learning for our valued students. It's about time for us to embrace those changes even if we left behind. 
On the other hand, it gives hope for those learner to improve their competency and skills. While the true test is the labor market, it is safe to say that we are moving toward upward direction.

\section{OLD SYSTEM}

- $\quad$ Students lack mastery of basic competencies due to a congested ten-year basic education curriculum.

- Graduates of the old curriculum are younger than 18 years old and are not legally ready to get a job or start a business.

Foreign countries perceive a ten-year curriculum as insufficient. They do not automatically recognize Overseas Filipino workers (OFWs) as professionals abroad.

Kindergarten (a strong foundation for lifelong learning and total development) is optional and not a pre-requisite for admission to Grade 1.

Old education system offers a broad curriculum that does not include enough practical applications.

Table No. IV OLD System before K to 12

Source: DepEd and http://k12philippines.com/

The old system lacks the competencies needed at the same time most countries accepts 12 years of instruction therefore we are left by 2 years. In some countries the degrees earned in the Philippines even if its Doctoral level are considered as masters level. This is because of 2 years less in terms of instruction. This is a major blow in many professionals as they are force to take additional years of instruction and certificates.

\section{K-12 EDUCATION SYSTEM}

- The K-12 program offers a decongested 12-year program that gives students sufficient time to master skills and absorb basic competencies.

Students of the new system will graduate at the age of 18 and will be ready for employment, entrepreneurship, middle level skills development, and higher education upon graduation.

The K-12 program accelerates mutual recognition of Filipino graduates and professionals in other countries.

Kindergarten is mandatory for five-year-old children, a pre-requisite for admission to Grade 1.

The new curriculum gives students the chance to choose among three tracks (i.e. Academic; Technical-Vocational-Livelihood; and Sports and Arts) and undergo immersion, which provides relevant exposure and actual experience in their chosen track.

Under the new system of K-12, we can say that we are more ready to face great challenge ahead as our learners will be more prepared in terms of skills and experience. Most countries accept 18 years old as employment age therefore our learner have the competitive advantage as their skills is within at par in the labor market. Technical skills and knowledge in ICT and foreign language(s) are now the most common skills desirable in both local and abroad.

\section{Practical Cost-Benefits of the K to 12 REFORM}

In any implementation of the law there are always cost and benefits attributed to it as a result of substantial change and development. According to Department of Education, the three (3) important highlights of the benefits can be viewed in the long term rather than short term. Therefore, we have to embrace the changes and challenges it brings.

\section{- Preparedness for Tertiary Learning}

When our learner reaches the age of maturity they became more matured and the choice of career and profession including decision making will be better. Once our student learner is a bit older (18) they can look for more possibilities as well opportunities. When skills are combined with their tertiary learning then our learners will be more equipped to the modern challenges in life. the extra 2 years of instruction is like a preparation for them to the choose career not only as a course in the tertiary level but to prepare them for their future. The mind set in preparing our learner is high at this stage as they can now choose which course or specialization they want to push thru.

\section{- Readiness to join the workforce}

If the learner decides to test their employability after their senior years then they are already eligible in terms of age requirements. In the industry and corporate world most employer prefer their prospective candidates to possess the necessary skills in performing the task assigned to them.

Those two years in the senior high school will be more than enough for them to prepare on this level. It is important for the senior high school to undergone training with TESDA (Technical Education and Skills Development Authority) as they are providing certificates and certification of skills which can be used in employment. Speaking of competitiveness, it is safe to say that our graduates in this level have the edge over other rivals.

-Skill competency in the global job market [11]

As the Senior high school offers four (4) tracks to choose from, each student can now look for areas of their interest. This will further enhance their decision making in the choice of career they want to push thru once they reach the tertiary level. They have also the option to work if they desire however the opportunities at this stage is very promising more than before. In combating poverty and insufficiency, education is perhaps the light of hope to most Filipinos. This light will guide them to reach for their dreams and destiny.

In dealing with the cost, the Philippine government introduces the voucher system which provides the affected learners with the subsidy from the government. The DepEd order no. 46 series 2015 facilitates the support and assistance by the Philippine government across the country. Furthermore, simplification of the documentation is their primary consideration especially in the urban and remote areas which the help and assistance is badly needed compare to those in the rural and city proper. 


\section{EVOLUTION OF SUBSTANTIAL SUPPORT AND Assistance by the PHILIPPINe Government}

Since the 2012 the evolution rather revolution of Education reforms takes place and this substantial changes were felt across classes of society in the Philippines. Below is the timeline of the many huge achievements that transform the education system to be more globally competitive than before.

Table No. V K to 12 Education System [10]

Source: DepEd and http://k12philippines.com/

\begin{tabular}{|c|l|}
\hline Year & \multicolumn{1}{|c|}{ Significant Contribution to Philippine Education } \\
\hline 2012 & Universal Kindergarten (RA 10157) \\
\hline 2013 & Enhance Basic Education (10533) K to 12 Program \\
\hline 2015 & $\begin{array}{l}\text { Detailed Guidelines on the Implementation of the } \\
\text { Senior High School Voucher Program } \\
\text { DepEd Order 46 }\end{array}$ \\
\hline 2015 & $\begin{array}{l}\text { BESRA (2007) REVISED GUIDELINES ON THE } \\
\text { HIRING OF TEACHER I POSITIONS BASED ON THE } \\
\text { REFORM ACTIONS IN BASIC EDUCATION SECTOR } \\
\text { REFORM AGENDA (BESRA) }\end{array}$ \\
\hline 2017 & $\begin{array}{l}\text { NCBTS (National Competency Based Teachers } \\
\text { Standards to PPST } \\
\text { National Adoption and Implementation of the } \\
\text { Philippine Professional Standards for Teachers } \\
\text { DepEd Order 42 }\end{array}$ \\
\hline 2017 & $\begin{array}{l}\text { Universal Access to Quality Education Act (RA } \\
\text { 10931) }\end{array}$ \\
\hline
\end{tabular}

Table No. VI Timeline of Basic Education to Higher Education Support since K12

Perhaps one of the take away of the substantial evolution is thru examination of learners. There is the National Achievement Test (NAT) being conducted across the region in the Philippines. Even if thru the years the score is stagnant still this practice was never being done across Asian countries. The welfare of the learner of the learner was the top priority

\begin{tabular}{|l|l|l|l|}
\hline Education Level & Public & Private & Total \\
\hline Elementary Schools & 38,648 & 10,561 & 49,209 \\
\hline Secondary Schools & 7,976 & 5,420 & 13,396 \\
\hline
\end{tabular}

Table No. VII Total Schools (Elementary and Secondary) As of $2017 *$ [12]

Source: Department of Education \& COA Report

Table No. 7 shows the public and private institutions engaged in the elementary and secondary level. Elementary has a total of 49,209 combine (public and private) while secondary accounts for 13,396 combine (public and private). It is obvious that elementary has more than triple as compared to secondary in terms of institutions. Therefore, the secondary level in terms of institution must increase. Thru the years we have seen many schools was badly damage by typhoons and other weather disturbance. This area should be the focus of attention by the government in order to achieve a better ratio of student against pupils. Aside from that the qualifications of the teacher are very important that's why the National Competency Based Teachers Assessment has been upgraded into Philippine Professional Standards for Teachers wherein teachers are classified from beginner to Distinguished. This kind of reform is needed at this stage specially for the teachers because other professions will not be possible without teacher. We a dedicated teacher in the Philippines despite their salary is not competitive. Because for them, it's the love of profession and be part of nation building. Perhaps it's about time that our government must take into consideration the hardships and sacrifices that our teachers have done. For their untiring support and assistance extended to our learners they deserve a better and competitive compensation. After all we might lose those talents and it will be a huge loss in the academic community.

\begin{tabular}{|c|c|}
\hline Higher Education & $\begin{array}{l}\text { Number of } \\
\text { Institutions }\end{array}$ \\
\hline Public & \\
\hline State U and Colleges & 112 \\
\hline Local Colleges and U & 107 \\
\hline Other Gov't Schools & 14 \\
\hline Private & 1,710 \\
\hline TOTAL & $\mathbf{1 , 9 4 3}$ \\
\hline
\end{tabular}

Table No. VIII Higher Educational Institution in the Philippines, 2017 [13] Source: Commission on Higher Education

Table no. 8 shows the breakdown of higher educational institution in the Philippines that is composed of public and private. The private sectors dominate this category which enlighten the government to push thru with more reforms in the higher education sector including the recently passed RA 10931 which provides subsidy to state colleges and university across the Philippines.

\section{LICENSURE EXAMINATION FOR TEACHERS FROM 2013-2018 (PERFORMANCE)}

The teaching profession in the Philippines is governed by the CHED and Professional Regulation Commission. Thru the years we have seen that there is a demand of teachers locally and internationally. In order to ensure that teachers in elementary and secondary are qualified and meet the global standards, there is a licensure examination that needs to be take and passed accordingly. Same its true in other profession like nursing, engineering and more. Having a licensure examination ensure the quality of teachers in the Philippines as the Licensure exam/board is one of the most difficult exam offered by the Professional Regulation Commission. 
Philippine Education System: Are we Moving Forward?

\begin{tabular}{|c|c|c|c|}
\hline Exam Date & $\begin{array}{c}\text { Total } \\
\text { Examinees } \\
\text { (Elementary } \\
\text { and } \\
\text { Secondary) }\end{array}$ & $\begin{array}{c}\text { Total } \\
\text { Passers }\end{array}$ & $\begin{array}{c}\text { Passing } \\
\text { Rate }\end{array}$ \\
\hline $\begin{array}{l}\text { September 30, } \\
2018\end{array}$ & 217,332 & 79,212 & $36.45 \%$ \\
\hline March 25, 2018 & 134,996 & 36,710 & $27.19 \%$ \\
\hline $\begin{array}{l}\text { September 24, } \\
2017\end{array}$ & 187,529 & 70,824 & $37.77 \%$ \\
\hline March 26, 2017 & 126,499 & 24,082 & $19.04 \%$ \\
\hline $\begin{array}{l}\text { September 25, } \\
2016\end{array}$ & 170,220 & 54,712 & $32.14 \%$ \\
\hline March 20, 2016 & 95,829 & 30,938 & $32.28 \%$ \\
\hline $\begin{array}{l}\text { September 27, } \\
2015\end{array}$ & 149,905 & 55,471 & $37.00 \%$ \\
\hline March 29, 2015 & 100,740 & 30,007 & $29.79 \%$ \\
\hline August 17, 2014 & 148,589 & 52,068 & $35.04 \%$ \\
\hline January 26, 2014 & 80,735 & 23,153 & $28.68 \%$ \\
\hline
\end{tabular}

THE PURPOSE, APPROPRIATING FUNDS THEREFOR, AND FOR OTHER PURPOSES". Our vision is a teacher education system whose mission is to educate and train teachers of unquestionable integrity and competence, and who are committed to their continuing professional growth and obligation to help their students grow as responsible individuals and citizens of the Philippines and of the world. [15] It only means that during the 1990s where the era of globalization transforms all over the world our teacher started to prepared for this. Therefore, on the part of policy makers and department secretary to push thru with more projects and programs for skills development of our teachers.

\section{CONCLUSION AND RECOMMENDATION}

In conclusion, we can say that the Philippine education system already reach its maturity since the time of colonialism up to the modern day globalization. Achieving the 12 years of basic education doesn't mean we are at par or competitive. We just achieve the global standard of years of instruction on this stage but the bigger challenge lies ahead. One of the major drawbacks includes decline in the admission in the collegiate level as a result of the changes. This problem is just temporary because all the education level is adjusting to this framework. By 2025 we can see a development out of those changes once our new breed of learner started to grow and prosper. The $\mathrm{K} 12$ is a major evolution in the Philippine Education system which validates the years of instruction. However, we must ensure that the two (2) extra years will really help them to acquire the skills and competency needed.

For individual, families and society in general, we can be proud of our siblings and family members' achievement if they graduated from primary, secondary, tertiary and above. Perhaps the literacy of the learners is one of the most important contribution of education. Aside from that as a citizen they are contributory to the economy thru employment or thru business opportunities. We are grooming the next generation of learners to value education not only the degrees earned but the work ethics and values attached to it.

Education as economic resources and nation building: Can be a long term contribution of education because it molds a nation where people are thinking for solution to help the government rather than inflicting differences and conflicts. From grass roots we have to incorporate the values of loving the flag and country.

This will be their motivation wherever they will go in the near future. We have to understand that basic education is the foundation of the studies of any learner and to ensure that the foundation is strong will definitely deliver a good result in the near future. Despite the challenges that both teachers and learners are facing the "never give up" spirit always prevail in the end.

We recommend that private sectors, non-governmental organization, and financial institution must be involved in the dialogue because the financial constraint still limits each and every learner to their full potential. If we can only pass a law that private sectors must adopt a school community, then the problem in financial and support will be minimize. We have many conglomerates and businesses across the country and their support will substantially affect the progress of any institution. TEACHER EDUCATION IN THE PHILIPPINES BY ESTABLISHING CENTERS OF EXCELLENCE, CREATING A TEACHER EDUCATION COUNCIL FOR 
Philippines is one of the country in Asia with a higher birth rate therefore the shortage of qualified teachers and classrooms must be increase by at least $10 \%$. Aside from that the social infrastructures must also be upgraded. Thanks to the "BUILD, BUILD, BUILD" project of the current administration (President Rodrigo Duterte) as it compliments the education system of our next generation.

We further recommend that teacher exchange program among ASEAN member countries will be encourage so each nations will have exposure and collaboration. This is a win-win solution among member nations. Another alternative is offering scholarship grants of funding for deserving teachers who wants to push thru with higher studies, training and other professional development activities including research and publication.

\section{FUTURE RESEARCH WORK}

There are many research areas that can be explored in the areas of education system. Comparable studies between Philippines and other ASEAN members can be a good exploratory study. The professions where many Filipinos excel can be a good research area to work on. Another interesting area to explore is what profession that our next generation of learners wants to be. How our pupils perform in the major areas like English, Science and Mathematics can be a good starting point of the study. Thru comparison we can determine if we are at par or we are left behind in the primary and secondary levels. Furthermore, we can explore research on the impact of the K12 to parents and families as implementation of this affect their lives.

\section{REFERENCES}

1. Antiado, D. F., Castillo, F. G. et al (2018). Educational Transformation in the Philippine Education System: Towards Global Competitiveness, The International Journal of Business Management and Technology, Volume 2 Issue 2 March 2018, p. 66-70 ISSN: 2581-3889

2. The Kindergarten Education Act (2012) "Universal Kindergarten Law", RA 10157, Republic of the Philippines.

3. Macha, W., et al (2018) "The Education System Profile, Available. [Online]. https://wenr.wes.org/2018/03/education-in-the-philippines.

4. Rappler News (2012) "P2.39 billion budget allocated for universal kindergarten law". Dated March 2012, Available. [Online]. https://www.rappler.com/nation/1998-p2-39-billion-budget-allocatedfor-universal-kindergarten-law.

5. UNESCO (2017) ISCED Level of Education., The International Standard Classification of Education. Available. [Online]. http://data.uis.unesco.org/

6. Edukasyon.ph news (n.d.) "What is Senior High school?" Available. [Online]. https://www.edukasyon.ph/courses/senior-high-tracks

7. Enhanced Basic Education Act of 2013 (2013) "AN ACT ENHANCING THE PHILIPPINE BASIC EDUCATION SYSTEM BY STRENGTHENING ITS CURRICULUM AND INCREASING THE NUMBER OF YEARS FOR BASIC EDUCATION, APPROPRIATING FUNDS THEREFOR AND FOR OTHER PURPOSES", RA 10533, Republic of the Philippines.

8. Edukasyon.ph news (2017) "Steps to Knowing Which Senior High School Track Best Fits You" Available. [Online]. https://www.ciit.edu.ph/senior-high-school-track/

9. Castillo, F. G. (2010) "INFORMATION AND COMMUNICATION TECHNOLOG IN TODAYS MODERN EDUCATION", Engineering Systems Management and Its Applications (ICESMA) Electronic ISBN: 978-9948-427-14-8 Available. [Online]. https://ieeexplore.ieee.org/xpl/conhome/5523174/proceeding

10. CITT Philippines (2015) "Why Push for K-12 Basic Education Program?' Available. [Online]. http//k12philippines.com/

11. CITT Philippines (2018) "Three Practical Benefits of the Philippines K12 Available. [Online]. http://k12philippines.com/three-practical-benefits-of-the-philippinesk-to-12-curriculum/
12. Department of Education Report (2017) Available. [Online] https://www.coa.gov.ph/phocadownloadpap/userupload/annual_audit _report/NGAs/2017/National-Government-Sector/Department-of-Edu cation/DepEd_ES2017.pdf

Commission of Higher Education (2017). Annual Report 2017 Available. [Online]. www.ched.gov.ph

13. LET Exam result (2019) Licensure Examination for Teachers, Available. [Online] https://www.thesummitexpress.com/2019/03/full-results-march-2019let-teachers-board-exam-list-of-passers-top-10.html

Official gazette (1994) " Teacher Education in the Philippines", Available.

[Online]

https://www.officialgazette.gov.ph/1994/08/04/republic-act-no-7784/

\section{AUTHORS PROFILE}

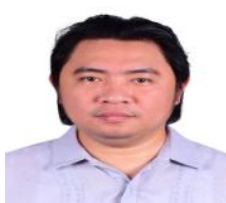

Dr. Fermin G. Castillo, Jr. -Associate Professor College of Business Administration / University of Sharjah, Sharjah, UAE. He holds a Post-doctora study in Total Quality Management (higher education) and Doctor of Business Administration from Centro Escolar University and University of the

\section{City of Manila.}

He is known for his field of specialization in management, marketing and strategic management. Not only a professor but he holds a valid teachers licensed/board exam and certification in his field of specialization which includes education, quality management, human resource management and strategic management. He is one of the few professors in the world who holds that's accomplishment. He also completed the Case Teaching method training offered at Harvard Business School, Boston, MA., USA. Aside from that he completed the UAE-Stanford University Innovation and Entrepreneurship, Coaching and High Impact Project Workshop.

He taught in undergraduate and post-graduate level in various institutions in the Philippines, Saudi Arabia, Malaysia and the United Arab Emirates. $\mathrm{He}$ won 4 international awards (2012 and 2013) in teaching and research (Best Professor Awards (HRM and Marketing) / Asian Achiever Award for Education) given by various organizations in Hong Kong, United Arab Emirates and Singapore. Under his leadership at University of Fujairah, they've won two international awards including Business School Leadership Award and Global Innovation Award given by TURNITIN. Recently he won the International Teaching Awards given by the Unified Fil-AM last May 2018 in Maryland, USA.

He attended more than 75 specialized trainings, workshops, seminars, and lectures in more than 10 countries including research publication workshops sponsored by UNESCO, USA and National Research Foundation, UAE. Dr Castillo plays active role in scholarly and research activities; in fact, he is one of the editorial board member/reviewer of various journal publications in USA, Canada, Hong Kong, Singapore, Malaysia, Indonesia and India.

Dr. Castillo is a professional/associate member of ILERA of the International Labor Organization, International Quality Federation, Asia Pacific Quality Organization, IEDRC and other international associations.

Aside from the accomplishment he achieved he still bring back to the community what he achieved by serving as the lead reviewer for the licensure examination for teachers since 2017 . He is adaptive to any work environment and his knowledge, skills and abilities will surely make any organization be in a competitive position.

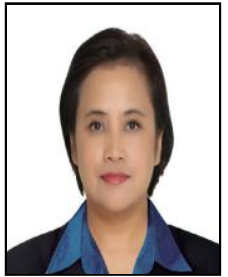

Dr. Djonde Frega Ariz Antiado holds the Assistant Professor and presently teaches at American College of Dubai (ACD). She has twenty years teaching experience in the collegiate level; courses taught include General Psychology, Psychology of Personality; Human Behavior in an Organization; Military Counselling; Introduction to the Social Sciences; Sociology; World History; Anthropology; Critical Thinking Techniques, Study Skills, GED-Social Studies and Business Communication 
Philippine Education System: Are we Moving Forward?

She held administrative functions in the tertiary level as Vice-President, Student Development Services \& Community Engagement, Dept Head for Social Sciences, Director of Guidance Services, Faculty Development \& Performance Evaluation Coordinator, Guidance Coordinator, Curriculum Development Specialist, and chaired and/member of committees related to research, curriculum development, examination, recruitment, and transfer of credits. She was assigned and involved in various committees to ensure quality standards or accreditation requirements in higher education; and completed training on program assessment.

She started her career as psychologist at the Philippine Military Academy (premiere officer training institution of the Armed Forces of the Philippines), then as guidance services specialist, and became a full-time faculty member of the Department of Social Sciences.

Before she moved to UAE she was accredited as psychologist of the Philippine National Police and Armed Forces of the Philippines.

Dr. Djonde Frega holds a doctorate degree of Educational Management; Master's in psychology and double majors in Psychology and Economics in the undergraduate level. She passed the Teacher's Licensure Examination (2002) and a CG (Cultural Intelligence) Certified Facilitator by the Cultural Intelligence Center, Holt Michigan.

She is actively involved in community engagement or outreach in UAE as a Resource Person or Speaker on topics related to Mental Health Awareness, Parenting in the Digital Age, Building a Safe and Caring School Climate that Deters Bullying, The Teacher as a Counselor, and Youth Depression; and volunteers as Counselor/Facilitator (Group Counselor) of distressed OFWs at the Philippine Consulate of Dubai.

She has research collaborations related to effective teaching, educational technology, peer mentoring, gender, social issues, skills development and HR management.

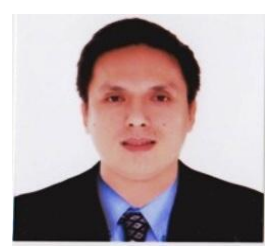

Dr. James Ryan P. Reblando graduated with a degree in Doctor of Management from the University of the Visayas, Master in Nursing major in Nursing Administration Services, Bachelor of Science in Nursing and Bachelor of Science in Biology. He has been accepted as one of the members of the IJARP Editorial Board and in IJSRED Editorial Board. He has recently published his first book under LAP LAMBERT Academic Publishing and available in amazon.com 